\title{
KEBUTUHAN KALSIUM AYAM BROILER FASE STARTER DENGAN PENAMBAHAN ENZIM FITASE
}

\section{CALCIUM REQUIREMENTS FOR STARTER PHASE BROILER CHICKENS WITH PHYTASE ENZYME ADDITION}

\author{
Eny Sholikhatin*, Ferry Poernama, Nanung Danar Dono, dan Zuprizal \\ Fakultas Peternakan, Universitas Gadjah Mada, Yogyakarta, 55281
}

Submitted: 2 August 2016, Accepted: 14 October 2016

\section{INTISARI}

\begin{abstract}
Penelitian ini bertujuan untuk mengetahui kebutuhan kalsium ayam broiler fase starter dengan penambahan enzim fitase. Penelitian menggunakan 1.200 ekor ayam broiler (mixed sex) yang dipelihara selama 21 hari pada kandang tipe closed house. Pakan basal disusun berbasis jagung dan bungkil kedelai dengan kandungan $\mathrm{Ca}$ 0,097\% dan P-av 0,123\%. Pakan perlakuan yang diberikan terdiri dari 6 macam pakan, yaitu P1 pakan basal dengan penambahan $0,42 \%$ non-phytate phosphorus (NPP) dan 0,90\% kalsium (Ca), kemudian pakan basal dengan penambahan 0,22\% NPP dan $1.000 \mathrm{FTU} / \mathrm{kg}$ fitase serta penambahan Ca dengan level yang berbeda, yaitu: 0,82\% (P2); 0,74\% (P3); 0,66\% (P4); 0,58\% (P5); dan 0,50\% (P6). Parameter yang diamati adalah kinerja pertumbuhan, efisiensi pakan, dan mineralisasi tulang. Penelitian didesain menggunakan Rancangan Acak Lengkap pola searah. Data yang berbeda nyata diuji lanjut menggunakan Duncan's new Multiple Ranges Test. Hasil penelitian menunjukkan bahwa pemberian 0,90\% Ca tanpa fitase dan penurunan level $\mathrm{Ca}$ dari $0,82 \%$ menjadi $0,50 \%$ dengan kombinasi fitase menaikkan jumlah pakan yang dikonsumsi pada keseluruhan fase pertumbuhan $(\mathrm{P}<0,05)$. Penambahan fitase memberikan efek yang menguntungkan dengan meningkatnya capaian rerata bobot badan $(P<0,05)$ maupun pertambahan bobot badan harian ayam $(P<0,05)$, dan menurunkan nilai FCR pada fase pengamatan umur 11 - 21 hari dan 1 - 21 hari. Penambahan fitase dapat meningkatkan konsumsi protein dan energi yang diikuti dengan peningkatan nilai PER dan EER $(P<0,05)$. Jika ke dalam pakan ditambahkan enzim fitase, penurunan $C a$ pakan hingga level 0,50\% tidak berefek buruk pada kadar abu tulang tibia. Dapat disimpulkan bahwa pemberian pakan dengan enzim fitase dapat mempertahankan kinerja pertumbuhan, efisiensi pakan, dan mineralisasi tulang.
\end{abstract}

(Kata kunci: Ayam broiler, Enzim fitase, Kebutuhan kalsium, Kinerja pertumbuhan, Mineralisasi tulang)

\section{ABSTRACT}

The aim of this study was to determine the calcium requirements of broiler chickens in starter phase with the addition of phytase enzyme. This experiment used 1,200 broiler chickens (mixed sex) for 21 days rearing period in a closed house. The basal diets was corn and soybean meal which contained $0.097 \% \mathrm{Ca}$ and $0.123 \% \mathrm{P}$-av. The treatments consisted of 6 diets treatment: P1 (basal diet with the addition of $0.42 \%$ non-phytate phosphorus (NPP), and then P2 to P6 were basal diet with the addition of $0.22 \%$ NPP and 1,000 FTU/kg phytase and the addition of calcium (Ca) at different levels: $0.82 \%(P 2)$; $0.74 \%$ (P3); $0.66 \%$ (P4); $0.58 \%$ (P5) and 0.50\% (P6). The growth performance, feed efficiency, and bone mineralization parameters were studied using Oneway ANOVA in a Completely Randomized Design. Duncan's new Multiple Ranges Test was used to separate means with significant differences. Results showed that $0.90 \%$ Ca supplementation without phytase and the reduction levels of $\mathrm{Ca}$ from $0.82 \%$ to $0.50 \%$ increased the amount of feed consumed by birds in all growth phases $(P<0.05)$. The addition of phytase had beneficial effects on increasing body weight $(P<0.05)$ and average of body weight gain $(P<0.05)$, and decreased the value of FCR in $11-21$ days and $1-21$ days. The addition of phytase increased protein and energy consumption, followed by increased in the value of PER and EER $(P<0.05)$. When phytase was added in the diets, reduction levels of $\mathrm{Ca}$ in the diets up to $0.50 \%$ did not give any adverse effect on the tibia bone ash. It can be concluded that feeding with phytase can sustain growth performance, feed efficiency, and bone mineralization.

(Key words: Bone mineralization, Broiler chickens, Calcium requirements, Growth performance, Phytase enzyme)

\footnotetext{
* Korespondensi (corresponding author):

Telp. +62 8137282 0006, E-mail: enysholikhatin07@gmail.com
} 


\section{Pendahuluan}

Bahan pakan unggas sumber energi didominasi oleh jagung dan gandum yang juga mengandung asam fitat. Asam fitat ini mengikat mineral fosfor (phosphorus ; P). Asam fitat juga mampu bereaksi mengikat unsur-unsur mineral bervalensi 2 atau 3 , seperti: kalsium, besi, seng, dan magnesium. Kalsium (Ca) merupakan salah satu kation divalen dengan afinitas terendah. Namun karena $\mathrm{Ca}$ adalah mineral yang ditambahkan dengan konsentrasi tertinggi dalam pakan unggas maka $\mathrm{Ca}$ mempunyai dampak lebih besar dalam membentuk chelate atau senyawa yang lebih kompleks daripada mineral lainnya. Senyawa kompleks yang terbentuk dapat menurunkan bioavaibilitas karena sulit diserap usus sehingga ketersediaan $\mathrm{Ca}$ bagi tubuh menjadi terbatas (Sebastian et al., 1996; Maenz et al., 1999; Tamim et al., 2004). Hal ini disebabkan karena ternak unggas secara alamiah hanya menghasilkan sedikit enzim fitase dalam tubuhnya yang penting untuk memecah kompleks fitat (Wolters, 1992; Rao et al., 1999; Rahayu, 2001). Apabila Ca dan P terikat oleh asam fitat, maka Ca dan $\mathrm{P}$ tidak dapat diserap, sehingga tidak dapat dimanfaatkan untuk metabolisme tubuh. Apabila nutrien mikro yang dibutuhkan untuk metabolisme kurang, maka ternak tidak dapat menampilkan potensi genetiknya yang sesungguhnya secara maksimal. Rasio $\mathrm{Ca}$ : $\mathrm{P}$ terbaik untuk mendapatkan kualitas tulang dan pertumbuhan yang optimum adalah 2:1 (Shafey, 1993).

Adanya dampak negatif apabila ternak kekurangan mineral $\mathrm{Ca}$ dan $\mathrm{P}$ atau keduanya mendorong para ahli pakan ternak untuk mencari kandidat bahan yang dapat ditambahkan dalam pakan unggas untuk memaksimalkan kecernaan asam fitat dalam tubuh ayam broiler. Salah satu alternatif yang telah ditemukan sebagai kandidat adalah dengan penambahan enzim fitase (Yan et al., 2006; Amerah et al., 2014). Pemberian enzim fitase pada pakan broiler diklaim dapat memecah atau menguraikan senyawa kompleks asam fitat sehingga $\mathrm{Ca}$ dapat dimanfaatkan secara lebih baik untuk kinerja pertumbuhan dan produksi dengan harapan ternak dapat menampilkan potensi genetik yang sesungguhnya. Penelitian ini bertujuan untuk mengetahui kebutuhan kalsium ayam broiler fase starter dengan penambahan enzim fitase dengan melihat kinerja pertumbuhan, efisiensi pakan, dan mineralisasi tulang sebagai respon parameter yang diamati.

\section{Materi dan Metode}

Sebanyak 1.200 ekor anak ayam broiler (mixed-sex), strain Lohmann MB-202 Platinum umur sehari digunakan dalam penelitian ini. Pakan basal disusun berbasis jagung dan bungkil kedelai dengan kandungan $\mathrm{Ca}$ 0,097\% dan $\mathrm{P}$-av 0,123\%. Komposisi pakan basal dan kandungan nutrien terhitung tersaji pada Tabel 1.

Pakan perlakuan yang diberikan terdiri dari 6 macam perlakuan dan setiap perlakuan diberikan replikasi 10 pen, masingmasing pen diberikan 20 ekor. P1 yaitu pakan basal dengan penambahan 0,42\% NPP dan 0,90\% Ca, kemudian pakan basal dengan penambahan 0,22\% NPP dan 1.000 FTU/kg fitase serta penambahan Ca dengan level yang berbeda, yaitu: 0,82\% (P2); 0,74\% (P3); 0,66\% (P4); 0,58\% (P5); dan 0,50\% (P6). Enzim fitase yang digunakan adalah enzim komersil dengan kandungan Schizosaccharomyces pombe. Enzim ditambahkan sebanyak $1.000 \mathrm{FTU} / \mathrm{kg}$ dalam ransum.

Pengambilan data konsumsi pakan, rerata bobot badan, pertambahan bobot badan (PBB), konversi pakan, dan efisiensi pakan dilakukan pada umur 0 s.d. 10 hari, 11 s.d. 21 hari, dan overall 0 s.d. 21 hari. Kadar abu tulang tibia diukur pada umur 21 hari. Sebelum dianalisis kadar abunya maka tulang tibia diekstraksi lemak menggunakan thermostat waterbath $\mathrm{HH}-6$. Tulang tibia bebas lemak selanjutnya dianalisis kadar abunya. Kadar abu tulang tibia ditetapkan dengan cara pengabuan pada suhu $600^{\circ} \mathrm{C}$ (AOAC, 1995).

Penelitian didesain menggunakan Rancangan Acak Lengkap pola searah. Data yang berbeda nyata diuji lanjut menggunakan Duncan's new Multiple Ranges Test.

\section{Hasil dan Pembahasan}

\section{Pengaruh penambahan enzim fitase dan penggunaan $\mathrm{Ca}$ berbeda level terhadap kinerja pertumbuhan ayam broiler}

Hasil penelitian (Tabel 2) menunjukkan bahwa penurunan level pemberian $0,50 \% \mathrm{Ca}$ (P6) dengan penambahan enzim fitase dan $0,22 \%$ NPP meningkatkan konsumsi pakan pada semua fase pengamatan. Perlakuan (P1) yang berfungsi sebagai kontrol menunjukkan konsumsi pakan yang tidak 
Tabel 1. Komposisi bahan pakan dan kandungan nutrien terhitung (feed composition and basal diet and nutrient content as analized)

\begin{tabular}{|c|c|}
\hline Bahan baku (ingredients) & Persentase (percentage) \\
\hline \multicolumn{2}{|c|}{ Bahan pakan penyusun ransum (\%) (feed composition) } \\
\hline Jagung lokal B (local corn B) & 58,093 \\
\hline Corn glutean meal & 4,142 \\
\hline Dried distiller grain with soluble & 3,095 \\
\hline Soy bean meal & 30,657 \\
\hline Palm olein & 2,390 \\
\hline DL-Methionine & 0,292 \\
\hline Garam (salt) & 0,203 \\
\hline L-Lysine $\mathrm{HCl}$ & 0,351 \\
\hline L-Threonine & 0,105 \\
\hline Sodium bicarbonat & 0,349 \\
\hline Protector mineral iii & 0,031 \\
\hline Choline $\mathrm{Cl} 60 \%$ & 0,036 \\
\hline PX BRO STARTER & 0,258 \\
\hline Total & 100,00 \\
\hline \multicolumn{2}{|l|}{ Kandungan nutrien (nutrients content) } \\
\hline Energi $(\mathrm{kcal} / \mathrm{kg})($ energy $(\mathrm{kcal} / \mathrm{kg}))$ & 3095 \\
\hline Protein kasar (\%) (crude protein (\%)) & 22,829 \\
\hline Serat kasar (\%) (crude fiber (\%)) & 2,546 \\
\hline Lemak kasar (\%) (crude fat (\%)) & 5,374 \\
\hline Bahan kering (\%) (dry matter (\%)) & 88,604 \\
\hline Kadar air (\%) (moisture (\%)) & 11,396 \\
\hline Abu (\%) (ash (\%)) & 3,451 \\
\hline Kalsium (\%) (calcium (\%)) & 0,097 \\
\hline Fosfor total (\%) (total phosphorus (\%)) & 0,370 \\
\hline NPP (\%) & 0,123 \\
\hline Sodium (\%) & 0,196 \\
\hline Potasium (\%) & 0,939 \\
\hline $\mathrm{M}+\mathrm{C}(\%)$ & 0,999 \\
\hline
\end{tabular}

jauh berbeda dengan perlakuan P2 - P5 pada fase pengamatan umur 11 - 21 hari dan overall 1 - 21 hari.

Hasil penelitian menunjukkan bahwa penurunan level penambahan $\mathrm{Ca}$ tidak mempengaruhi nilai rerata capaian bobot badan dan PBB pada periode umur 1 - 10 hari, namun pada fase pengamatan umur 11 - 21 hari dan 1 - 21 hari meningkatkan rerata capaian bobot badan dan PBB dengan penambahan 0,74\% Ca (Tabel 2). Enzim fitase yang ditambahkan dalam ransum dengan kadar $\mathrm{Ca}$ tinggi (P2) diduga juga akan berkompetisi dengan $\mathrm{Ca}$ dalam mengambil posisi aktif dari fitat, kompetisi ini mengakibatkan fitat tidak terhidrolisis secara sempurna (Solomons, 1988). Hasil ini sesuai dengan penelitian Schoner et al. (1993) yang menunjukkan bahwa penambahan fitase dengan $0,60 \% \mathrm{Ca}$ memiliki bobot badan yang lebih tinggi dibandingkan dengan penambahan 0,90\% Ca. Liem (2009) juga melaporkan bahwa penurunan pemberian konsentrasi $0,90 \%$ Ca menjadi $0,60 \% \mathrm{Ca}$ dengan penambahan fitase meningkatkan rerata bobot badan pada ayam broiler yang dipelihara selama 16 hari.

Penurunan level penambahan $\mathrm{Ca}$ hingga $0,74 \%$ atau lebih rendah lagi meningkatkan nilai capaian rerata bobot badan dan PBB $(P<0,05)$ dibandingkan perlakuan kontrol dengan penambahan 0,90\% Ca (P1). Pemberian Ca dengan level terrendah $(0,50 \%)$ dengan penambahan enzim fitase lebih efisien dilihat dari data capaian bobot badan dan PBB ayam broiler yang dipelihara selama 21 hari. Hal ini diduga disebabkan karena enzim fitase yang 
diberikan dalam pakan bekerja secara efektif memecah ikatan kompleks asam fitat sehingga $\mathrm{Ca}$ dan $\mathrm{P}$ lebih tersedia dalam digesta pakan untuk menghasilkan pertumbuhan yang optimal.

Data hasil penelitian pada variabel FCR menunjukkan bahwa pada fase pengamatan 11 - 21 hari dan 1 - 21 hari penurunan pemberian $\mathrm{Ca}$ dalam pakan menurunkan nilai FCR ketika pakan ditambahkan dengan enzim fitase (Tabel 2). Penambahan fitase dalam pakan, meskipun tingkat $\mathrm{Ca}$ terendah yaitu 0,50\% cukup untuk mendukung tingkat pengoptimalan hidup ternak karena dapat meningkatkan absorpsi nutrien yang lebih baik. Hasil ini sesuai dengan penelitian Amerah et al. (2014) bahwa penambahan fitase dalam ransum dapat memperbaiki bobot badan, konsumsi pakan, dan nilai FCR pada ayam broiler yang dipelihara selama 21 hari.

\section{Pengaruh penambahan enzim fitase dan penggunaan $\mathrm{Ca}$ berbeda level terhadap efisiensi pakan}

Hasil analisis variansi (Tabel 3) menunjukkan bahwa pada semua fase pengamatan konsumsi protein meningkat pada perlakuan dengan pemberian 0,50\% $\mathrm{Ca}(\mathrm{P} 6)$, sedangkan pada fase pengamatan umur 1 - 10 hari konsumsi protein meningkat pada pemberian $0,58 \%$ Ca (P5). Hasil penelitian juga menunjukkan bahwa pada fase pengamatan umur 11 - 21 hari dan 1 21 hari penurunan level pemberian $0,66 \% \mathrm{Ca}$ dalam pakan meningkatkan nilai PER dibandingkan penambahan 0,90\% Ca (P1), namun penurunan hingga $0,50 \% \mathrm{Ca}(\mathrm{P} 6)$ menurunkan nilai PER $(P<0,05)$ meskipun ke dalam pakannya telah ditambahkan enzim sitase sebanyak 1.000 FTU. Semakin rendah nilai PER maka nilai efisiensi pakan juga semakin menurun.

Data hasil penelitian (Tabel 3) menunjukkan bahwa pada fase pengamatan umur 1 - 10 hari yang mendapat penambahan 1.000 FTU fitase, penurunan level $\mathrm{Ca}$ pakan tidak mempengaruhi nilai PER. Hal ini diduga karena enzim fitase yang diberikan bekerja secara aktif memecah ikatan kompleks asam fitat sehingga protein dan Ca lebih tersedia dalam tubuh.

Hasil penelitian menunjukkan bahwa penambahan $0,50 \% \mathrm{Ca}(\mathrm{P} 6)$ pada pakan yang mendapat tambahan fitase 1.000 FTU menaikkan konsumsi energi pada fase pengamatan umur 11 - 21 hari dan 1 - 21 hari. Sedangkan pada umur 1 - 10 hari konsumsi energi meningkat pada penambahan 0,58\% Ca (P5). Hal ini diduga karena ayam memiliki insting untuk mengkonsumsi pakan ketika kebutuhan nutrien $\mathrm{Ca}$ dan $\mathrm{P}$ dalam tubuhnya belum terpenuhi. Kingori et al. (2003) menyatakan bahwa ternak hanya akan mengkonsumsi pakan yang memiliki kandungan nutrien sesuai dengan nutrien yang dibutuhkan tubuhnya.

Hasil penelitian pada variabel EER menunjukkan bahwa pakan yang mendapat suplementasi 1.000 FTU fitase meningkatkan nilai EER pada fase pengamatan umur 11 21 hari. Namun demikian, penurunan level pemberian $\mathrm{Ca}$ dalam pakan tidak mempengaruhi perlakuan di fase pengamatan umur 1 - 10 hari dan 1 - 21 hari. Hal ini menunjukkan bahwa penggunaan ransum sudah efisien dan enzim fitase mampu berkerja secara efektif memecah ikatan kompleks asam fitat sehingga $P$ dapat dimanfaatkan secara optimal dalam transfer energi di dalam sel melalui pembentukan Adenosine Triphosphate (ATP). Shelton et al. (2004) menyatakan bahwa enzim fitase mampu menghidrolisis asam fitat, sehingga dapat meningkatkan protein dan energi serta kandungan $\mathrm{Ca}$ dan $\mathrm{P}$ pada broiler. Terdapat beberapa faktor yang mempengaruhi kerja enzim fitase antara lain konsentrasi fitat, taraf pemberian enzim fitase, karakteristik enzim fitase, sumber fitase, dan ukuran pakan (Amerah dan Ravidran, 2009).

\section{Pengaruh penambahan enzim fitase dan penggunaan $\mathrm{Ca}$ berbeda level terhadap mineralisasi tulang}

Data hasil penelitian pada Tabel 4 menunjukkan bahwa kadar abu tulang tibia ayam broiler umur 21 hari yang mendapat penambahan 1.000 FTU fitase tidak berkurang/menurun meskipun suplementasi $\mathrm{Ca}$ diturunkan hingga 0,50\% (P6). Suplementasi enzim fitase tersebut mampu mempertahankan kadar abu tibia. Hal ini diduga disebabkan karena enzim fitase yang diberikan dalam pakan bekerja secara efektif memecah ikatan kompleks asam fitat sehingga $\mathrm{Ca}$ dan $\mathrm{P}$ lebih tersedia dalam digesta pakan. Ketersediaan $\mathrm{Ca}$ dan $\mathrm{P}$ dalam saluran pencernaan memungkinkan suplai $\mathrm{Ca}$ dan $\mathrm{P}$ untuk pertumbuhan tulang menjadi cukup. Kadar abu tibia ayam broiler tidak berbeda meskipun level penambahan $\mathrm{Ca}$ diturunkan hingga 0,50\%. 


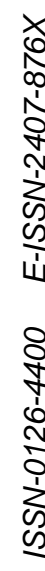

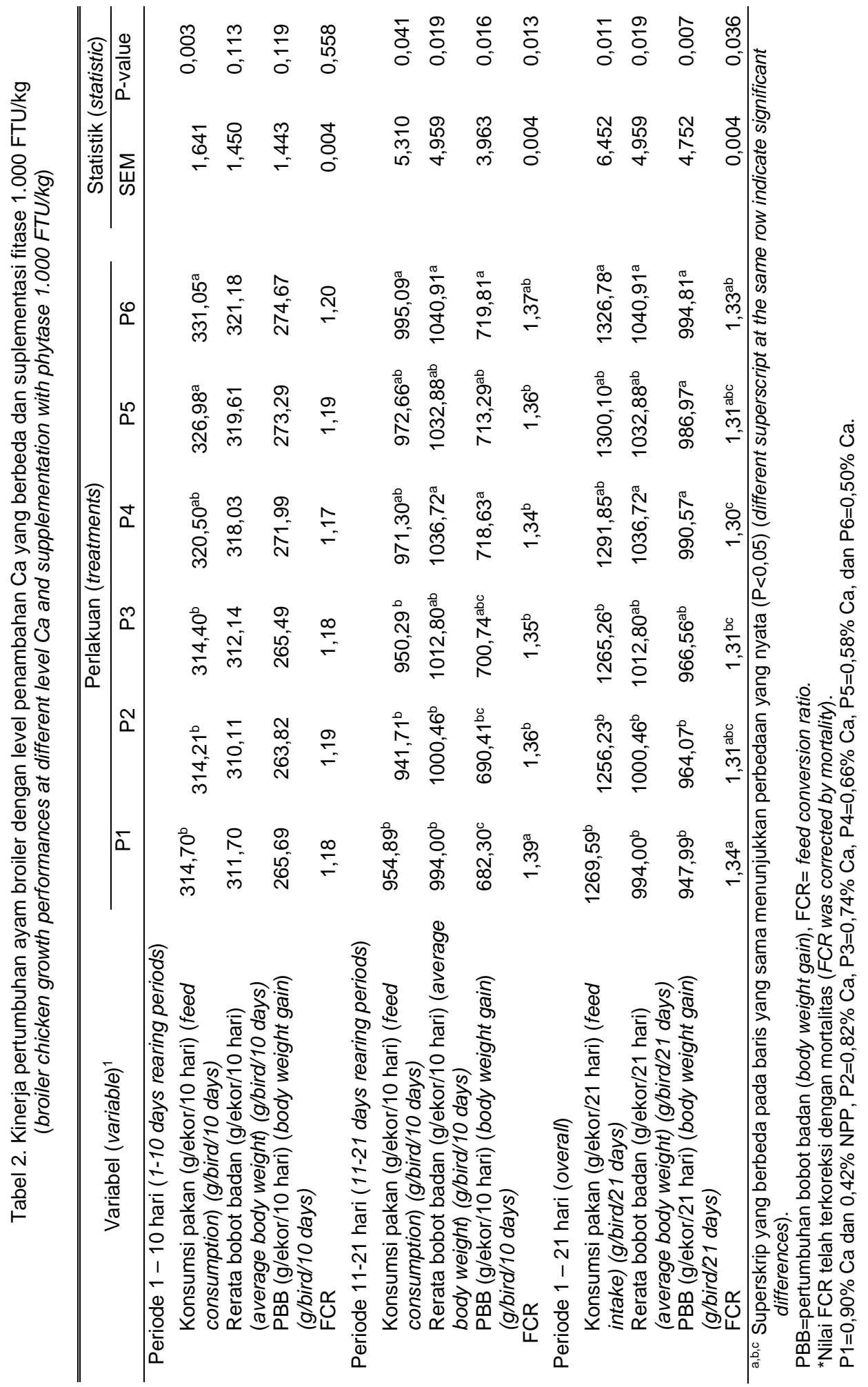




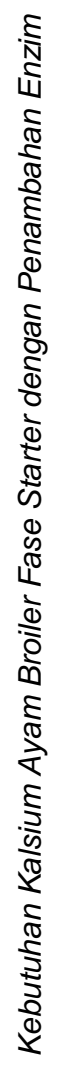

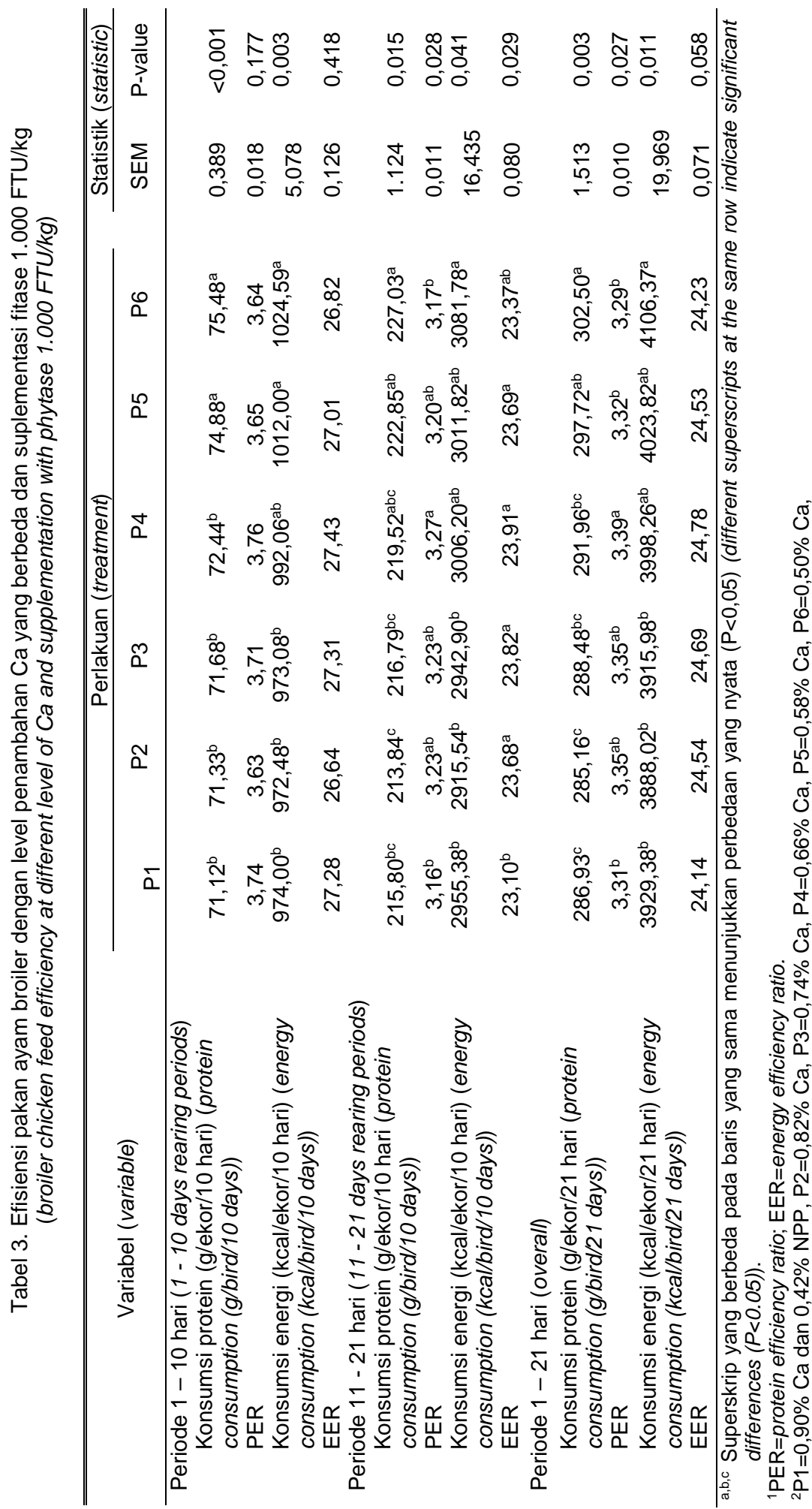


Tabel 4. Persentase kadar abu tulang tibia ayam broiler dengan level penambahan Ca yang berbeda dan suplementasi fitase $1.000 \mathrm{FTU} / \mathrm{kg}$

(broiler chicken tibia bone ash content at different level of Ca and supplementation with phytase $1.000 \mathrm{FTU} / \mathrm{kg}$ )

\begin{tabular}{|c|c|c|c|c|c|c|c|c|}
\hline \multirow{2}{*}{ Variabel } & \multicolumn{6}{|c|}{ Perlakuan (treatments) } & \multicolumn{2}{|c|}{ Statistik (statistic) } \\
\hline & P1 & $\mathrm{P} 2$ & P3 & $\mathrm{P} 4$ & P5 & P6 & SEM & $P$-value \\
\hline $\begin{array}{l}\text { Kadar abu tibia (tibia bone ash } \\
\text { content) }\end{array}$ & 53,44 & 52,50 & 52,94 & 52,02 & 51,78 & 51,99 & 0,198 & 0,101 \\
\hline
\end{tabular}

Driver et al. (2005) menyatakan bahwa penurunan level pemberian Ca dari $0,98 \%$ sampai $0,38 \%$ dengan NPP $0,58 \%$ dengan penambahan fitase tidak memberikan pengaruh terhadap kadar abu tibia ayam broiler yang dipelihara selama 16 hari. Namun demikian, Powell et al. (2010) menyatakan bahwa suplementasi fitase dengan level $\mathrm{Ca}$ yang tinggi dapat meningkatkan kekuatan tulang, berat tulang, berat abu, dan persentase kadar abu tibia. Brenes et al. (2003) menambahkan bahwa kadar abu tibia meningkat (sampai 4\%), Ca (sampai 2\%), dan P (sampai 1\%) oleh suplementasi fitase. Perbedaan data hasil penelitian diduga disebabkan karena perbedaan materi dan metode penelitian yang digunakan seperti: perbedaan sumber fitase yang digunakan, level pemberian enzim fitase, karakteristik enzim fitase, ukuran partikel pakan, level Ca dan $\mathrm{P}$ pakan perlakuan, komposisi bahan pakan, rasio Ca:P pakan perlakuan, suhu dan waktu pembuatan pellet dan sebagainya (Pasamontes et al., 1997; Angel et al., 2006; Ravindran et al., 2006; Amerah dan Ravindran, 2009; Selle et al., 2009). Faktor lain yang mungkin telah memberi kontribusi pada hasil yang tidak konsisten adalah pembentukan Ca-fitat kompleks yang tidak rentan terhadap degradasi enzim fitase (Angel et al., 2002; Selle et al., 2009).

Sumber fitase yang digunakan dalam penelitian ini berasal dari jamur Schizosaccharomyces pombe dengan $\mathrm{pH}$ yang optimal lebih tinggi, dan mungkin mempunyai kemampuan respon yang lebih kuat terhadap penghambatan kompleks Ca-fitat. Berdasarkan penelitian sebelumnya (Brana et al., 2005), penggunaan enzim fitase dengan kandungan Schizosaccharomyces pombe terbukti lebih efektif dalam melepas fitat yang mengikat mineral $\mathrm{Ca}$ dan $\mathrm{P}$ bila dibandingkan dengan Aspergillus niger.

\section{Kesimpulan}

Penurunan level penambahan $\mathrm{Ca}$ pakan dengan penambahan 1.000 FTU fitase menaikkan konsumsi pakan, konsumsi protein, konsumsi energi, serta menurunkan nilai FCR pada fase pengamatan umur 11 21 hari dan 1 - 21 hari. Pemberian $\mathrm{Ca}$ dengan level terendah (0,50\%) dengan penambahan enzim fitase lebih efisien dilihat dari capaian bobot badan dan PBB ayam broiler yang dipelihara selama 21 hari. Penurunan $\mathrm{Ca}$ pakan hingga level 0,50\% juga tidak berefek buruk pada kadar abu tulang tibia.

\section{Daftar Pustaka}

AOAC. 1995. Official Methods of Analysis of The Association of Official Analytical Chemists. AOAC Int., Washington D.C.

Amerah, A. M. and V. Ravindran. 2009. Influence of particle size and microbial phytase supplementation on the performance, nutrient utilisation and digentive tract parameters of broiler starter. J. Anim. Prod. Sci. 49: 704710.

Amerah, A. M., P. W. Plumstead, L. P. Barnard and A. Kumart. 2014. Effect of calcium level and phytase addition on ileal phytate degradation and amino acid digestibility of broilers fed cornbased diets. Poult. Sci. 93: 906-915.

Angel, R., N. M. Tamim, T. J. Applegate, A. S. Dhanu and L. E. Ellestad. 2002. Phytic acid chemistry: Influence on phytin-phosphorus availability and phytase efficacy. J. Appl. Poult. Res. 11: 471-480.

Angel, R., W. W. Saylor, A. D. Mitchell, W. Powers and T. J. Applegate. 2006. Effect of dietary phosphorus, phytase, and 25-hydroxycholecalciferol on broiler chicken bone mineralization, 
litter phosphorus, and processing yields. Poult. Sci. 85: 1200-1211.

Brana, D. V., M. Ellis, E. O. Castaneda, J. S. Sands and D. H. Baker. 2005. Effect of a novel phytase on growth performance, bone ash, and mineral digestibility in nursery and growerfinisher pigs. J. Anim. Sci. 84: 18391849.

Brenes, A., A. Viveros, I. Arija, C. Centeno, M. Pizarro and C. Bravo. 2003. The effect of citric acid and microbial phytase on mineral utilization in broiler chicks. Anim. Feed Sci. Tech. 110: 201-219.

Driver, J. P., G. M. Pesti, R. I. Bakali and H. M. Edwards. 2005. Effect of calcium and nonphytate phosphorus concentrations on phytase efficacy in broiler chicks. Poult. Sci. 84: 14061417.

Kingori, A. M., J. K. Tuitoek, H. K. Muiruri and A. M. Wachira. 2003. Protein requirements of growing indigenous chickens during the 14-21 weeks growing period. J. Anim. Sci. 33: 7882.

Liem, A. 2009. Dietary factors influencing calcium and phosphorus utilization by broiler chicks. Thesis. The University of Georgia, Georgia.

Maenz, D. D., C. M. Engele-Schan, R. W. Newkirk and H. L. Classen. 1999. The effect of minerals and mineral chelators on the formation of phytaseresistant and phytase-susceptible forms of phytic acid in solution and in a slurry of canola meal. Anim. Feed Sci. Tech. 81: 177-192.

Pasamontes, L., M. Haiker, M. Wyss, M. Tessier and A. P. van Loon. 1997. Gene cloning, purification, and characterization of a heat-stable phytase from the fungus Aspergillus fumigatus. J. Appl. Environment. Microbiol. 63: 1696-1700.

Rahayu, I. D. 2001. Fitase mikrobial sebagai sumber mineral. Poult. Ind. 259: 48-50.

Rao, S. V. R., V. R. Reddy and R. V. Ravindran. 1999. Enhancement of phytase phosphorus availability in the diets of commercial broiler and layers. J. Anim. Feed Sci. Tech. 79: 211-222.

Ravindran, V., S. Cabahug, G. Ravindran and W. L. Bryden. 2006. Influence of microbial phytase on apparent ileal amino acid digestibility of feedstuffs for broilers. Poult. Sci. 78: 699-706.
Powell, S., T. D. Bidner and L. L. Southern 2010. Phytase supplementation improved growth performance and bone characteristics in broilers fed varying levels of dietary calcium. Poult. Sci. 90: 604-608.

Schoner, F. J., P. P. Hoppe, G. Schwarz and H. Wiesche. 1993. Effects of microbial phytase and inorganic phosphate in broiler chickens: performance and mineral retention at various calcium levels. J. Anim. Physiol. Nutr. 69: 235244.

Sebastian, S., S. P. Touchburn, E. R. Chavez and P. C. Lague. 1996. Efficacy of supplemental microbial phytase at different dietary calcium levels on growth performance and mineral utilization of broiler chickens. Poult. Sci. 75: 1516-1523.

Selle, P. H., A. J. Cowieson and V. Ravindran. 2009. Consequences of calcium interactions with phytate and phytase for poultry and pigs. J. Livest. Sci. 124: 126-141.

Shafey, T. M. 1993. Calsium tolerance of growing chickens: effect of ratio of dietary calcium interactions with phytate and phytase for poultry and pigs. J. Livest. Sci. 124: 126-141.

Shelton, J. L., L. L.Southern, L. A. Gaston and A. Foster. 2004. Evaluation of the nutrient matrix values for phytase in broilers. J. Appl. Poult. Res. 13: 213221.

Solomons, N. W. 1988. In Modern Nutrition in Health and Disease, $7^{\text {th }}$ edn. Lea and Febiger, Philadelphia.

Tamim, N. M., R. Angel and M. Christman. 2004. Influence of dietary calcium and phytase on phytate phosphorus hydrolyses in broiler chickens. Poult. Sci. 83: 1358-1367.

Wolters, M. G. E. 1992. Prediction of the bioavalibilityof minerals and trace elements in foods: The influence of dietary fibre, phytic acid and other food components on the in vitro availability of calcium, magnesium, iron, copper, and zinc. Disertation. Landbouw Universiteit te Wageningen, Wageningen.

Yan, F., J. H. Kersey, C. A. Fritts and P. W. Waldroup. 2006. Effect of phytase supplementation on the calcium requirement of broiler chicks. Poult. Sci. 5: 112-120. 